\title{
The Effect of Wages, Investment, Number of Industrial Units, and Number of Job Opportunities on the Level of Migration to DKI Jakarta in 2008-2019
}

\author{
Wiji Trisetiyo $^{1 *}$, Meidy Haviz ${ }^{2}$ \\ ${ }^{1,2)}$ Universitas Islam Bandung, Jl. Tamansari No.1 Bandung \\ Corresponding Author Email: tiyowiji@gmail.com
}

Received: 19 / 09 / 2020

Accepted: 29 / 09 / 2020

Keywords: Migration, Wages, Investment, Industrial Units, and Job Opportunities.

\begin{abstract}
One of the cities in Indonesia that has quite rapid economic progress is DKI Jakarta. The high minimum wage, investment, number of industrial units, and job opportunities in DKI Jakarta are factors that attract people to migrate to this city. However, in reality, the growth of in-migration to DKI Jakarta in the 2008-2019 period tends to show a decline. This study aims to determine the influence and magnitude of the effect of wages, investment, number of industries, and employment opportunities on in-migration to DKI Jakarta in 2018-2019. The analysis method used is multiple linear regression analysis and the method of least squares Ordinary Least Square (OLS). While the types and methods of research used in this research are descriptive quantitative and verification methods. The data used are data on provincial minimum wages, investment, industrial units, job opportunities, and data on incoming migration in DKI Jakarta in the 2008-2019 timeframe. The data in this study came from the Central Bureau of Statistics. The results showed that the provincial minimum wage (UMP) and investment (INV) variables partially affected the incoming oil (MM) to DKI Jakarta in 2008-2019. Meanwhile, the industrial unit variable (UIN) and the variable number of job opportunities (KKJ) partially did not affect in-migration to DKI Jakarta (MM) in 2008-2019. This research implies that in dealing with the high rate of population movement, the government needs to implement policies to overcome it such as increasing the provincial minimum wage, investment, the number of industrial units.
\end{abstract}

\section{INTRODUCTION}

The migration of residents from rural areas or remote areas to cities occurs based on several options. One of them is the option to find a better living. Either the reasons for the economy or the choice of education, culture, and more adequate facilities. The migration of rural residents to cities is considered to be a solution for people with weak socio-economic conditions to meet their needs properly. Economic growth in cities that is better than in villages and the concentration of various economic activities in urban areas encourage people to migrate. Many studies on migration show that the reasons for migration are mainly economic, namely the opportunity to get a better job and/or a bigger income (Tjiptoherjanto, 1999). Apart from economic factors, Social and cultural factors are also reasons that cannot be separated from the consideration that people migrate. Several previous studies on migration, such as research conducted by Rizal (2004), showed that the type of work, level of education, city facilities, village impetus, and land ownership status influenced the decision to carry out circular migration for workers in Medan. Talking about economic factors is closely related to wages or the level of income earned. Many villagers see neighbors or relatives who work in the city as earning large wages and good fortune. This condition triggers a stronger desire to go to the city. The level of salary or wages earned in the village has not been able to guarantee and sufficient for the welfare of migrants and their families. The difference in wage levels between rural and urban areas encourages residents to migrate to cities to fulfill increasingly diverse needs. In effect, new residents will decide to migrate if the net income in the city exceeds the net income available in the village (Todaro, 2004). Weak economic progress and the lack of investment aimed at the industrial and agricultural sectors in rural areas have resulted in rural industries being difficult to develop and unable to absorb the workforce in these villages. This investment has a very important role in supporting development in both the private and government sectors. This investment can increase production or capital costs. Capital accumulation efforts can be through investment activities, which will then drive the economy through the mechanism of aggregate demand, where this investment will increase production efforts and in the end, will be able to increase labor demand which then becomes a pulling factor for labor to migrate (Anggraeny, 2016). The high population growth reaches a very high level, the lack of jobs and industrial units available in the area of origin encourages people to move to places that have more industry and employment fields. The growth of business units in an area will increase the number of jobs, when the number of jobs increases, job opportunities will also experience an increase, 
and the impact on labor demand will also experience an increase. If the business unit of an industry is added, the demand for labor will also increase (Dewi, 2012). Along with the increase in job opportunities, there will be more job opportunities in big cities, this will encourage rural residents to migrate to cities to find alternatives and jobs with higher wages, especially in big cities like Jakarta have greater job opportunities. in the industrial sector (Todaro, 2004). The movement of the population from rural to urban areas reflects differences in growth and inequality of development facilities between rural areas and urban areas (Tjahyati, 2016). As long as there are differences, population migration will continue. Moreover, it has become a generally recognized fact that in some developing countries, the concentration of investment and resources is generally in urban areas. As the capital of the country, the center of government and commerce, Jakarta shows quite impressive development for everyone. With such rapid development, this city has created a large expansion of employment opportunities. The attractiveness of Jakarta as the national capital or center of government and economic center is certainly a magnet for residents outside Jakarta to come to this city. Apart from that, Jakarta also offers quite high wages or salaries. The expertise or ability of a person in the field of work that is controlled is necessary for prospective migrants who decide Jakarta as a place to live as well as a place to work, either as industrial workers or office workers or in other professional fields. the center of government and commerce, Jakarta shows quite impressive development for everyone. With such rapid development, this city has created a large expansion of employment opportunities. The attractiveness of Jakarta as the national capital or center of government and economic center is certainly a magnet for residents outside Jakarta to come to this city. Apart from that, Jakarta also offers quite high wages or salaries. The expertise or ability of a person in the field of work that is controlled is necessary for prospective migrants who decide Jakarta as a place to live as well as a place to work, either as industrial workers or office workers or in other professional fields. the center of government and commerce, Jakarta shows quite impressive development for everyone. With such rapid development, this city has created a large expansion of employment opportunities. The attractiveness of Jakarta as the national capital or center of government and economic center is certainly a magnet for residents outside Jakarta to come to this city. Apart from that, Jakarta also offers quite high wages or salaries. The expertise or ability of a person in the field of work that is controlled is necessary for prospective migrants who decide Jakarta as a place to live as well as a place to work, either as industrial workers or office workers or in other professional fields. With such rapid development, this city has created a large expansion of employment opportunities. The attractiveness of Jakarta as the national capital or center of government and economic center is certainly a magnet for residents outside Jakarta to come to this city. Apart from that, Jakarta also offers quite high wages or salaries. The expertise or ability of a person in the field of work that is controlled is necessary for prospective migrants who decide Jakarta as a place to live as well as a place to work, either as industrial workers or office workers or in other professional fields. With such rapid development, this city has created a large expansion of employment opportunities. The attractiveness of Jakarta as the national capital or center of government and economic center is certainly a magnet for residents outside Jakarta to come to this city. Apart from that, Jakarta also offers quite high wages or salaries. The expertise or ability of a person in the field of work that is controlled is necessary for prospective migrants who decide Jakarta as a place to live as well as a place to work, either as industrial workers or office workers or in other professional fields. The attractiveness of Jakarta as the state capital or center of government and economic center is certainly a magnet for residents outside Jakarta to come to this city. Apart from that, Jakarta also offers quite high wages or salaries. The expertise or ability of a person in the field of work that is controlled is necessary for prospective migrants who decide Jakarta as a place to live as well as a place to work, either as industrial workers or office workers or in other professional fields. The attractiveness of Jakarta as the state capital or center of government and economic center is certainly a magnet for residents outside Jakarta to come to this city. Apart from that, Jakarta also offers quite high wages or salaries. The expertise or ability of a person in the field of work that is controlled is necessary for prospective migrants who decide Jakarta as a place to live as well as a place to work, either as industrial workers or office workers or in other professional fields.

Table 1 Total Incoming Migration, Provincial Minimum Wage, Investment, Industrial Units, and Job Opportunities in DKI Jakarta, 2008-2019.

\begin{tabular}{crrrrr}
\hline Year & $\begin{array}{c}\text { Inbound } \\
\text { Migration }\end{array}$ & $\begin{array}{c}\text { Provincial Minimum } \\
\text { Wage }\end{array}$ & \multicolumn{1}{l}{ Investation } & Industrial Unit & $\begin{array}{c}\text { Employment } \\
\text { Opportunity }\end{array}$ \\
\hline 2008 & 88473 & 972605 & 95965885000 & 1866 & 11408 \\
2009 & 69554 & 1069865 & 52072111000 & 699 & 15778 \\
2010 & 59215 & 1188010 & 58094620869 & 1588 & 472898 \\
2011 & 51875 & 1290000 & 43970368404 & 1451 & 200391 \\
2012 & 47832 & 1529150 & 39927372749 & 1410 & 42487 \\
2013 & 150322 & 2200000 & 31728880834 & 1241 & 44163 \\
2014 & 96034 & 2441000 & 56610317078 & 1240 & 124750 \\
2015 & 160243 & 2700000 & 48877304725 & 1323 & 19093 \\
2016 & 219427 & 3100000 & 45887916900 & 1199 & 46140 \\
2017 & 175234 & 3355750 & 61160734635 & 2582 & 30710 \\
2018 & 69000 & 3648035 & 70520186533 & 1632 & 25132 \\
\hline
\end{tabular}




\begin{tabular}{cccccr}
\hline Year & $\begin{array}{c}\text { Inbound } \\
\text { Migration }\end{array}$ & $\begin{array}{c}\text { Provincial Minimum } \\
\text { Wage }\end{array}$ & Investation & Industrial Unit & $\begin{array}{c}\text { Employment } \\
\text { Opportunity }\end{array}$ \\
\hline 2019 & 35209 & 3940972 & 57375917800 & 2374 & 34038 \\
\hline \multicolumn{5}{c}{ Source: Department of Population and Civil Registry and BPS DKI Jakarta, 2008-2019 } \\
\hline
\end{tabular}

When viewed from the trend of migration growth in Jakarta, migration tends to show more decline. The significant increase in migration growth in Jakarta only occurred in 2013, 2015, and 2016. Apart from these years, the number of inmigration to Jakarta has always decreased. The decline in in-migration growth is the result of a decline in Jakarta's wage growth which has also decreased. Rational workers with increasingly expensive living costs in Jakarta are not comparable to the wages they will get each month, so workers have started to look to Jakarta's buffer zones such as Depok, Tanggerang, Bekasi, Bogor Regency, and also Karawang. The shifting of migration destination cities has started to occur since early 2010, this is further strengthened by the high number of net migration in Depok, Tangerang, Bekasi, and also Bogor Regency this year. The next shift in migration occurred again in 2015 due to the decline in existing employment opportunities in 2015. Most migrants from their hometown aim to go to Jakarta to look for work, but once in Jakarta they do not find the job they want, migrants will move to the suburbs of Jakarta. The total value of an investment, industrial units, and job opportunities in Jakarta has changed up and down every year. The highest growth in job opportunities, which was quite drastic, occurred in 2010, amounting to $2897 \%$, where the growth occurred because the number of industries and investments in Jakarta also increased. Investments that are of interest to investors this year are an investment in the industrial sector which absorbs a lot of labor. Investment in 2010 increased by $12 \%$ but in terms of the number of industrial units, it increased by $127 \%$ or an increase of 889 industrial units. The manufacturing industry, trade industry, and construction industry in 2010 grew rapidly in number, the increasing number of industrial units expanded job opportunities that could absorb labor in Jakarta. While the lowest growth in employment opportunities occurred in 2015 , namely $-85 \%$ or reduced employment opportunities by 105,657 people, this reduction in job opportunities is also the impact of reduced investment and small growth in the number of existing industries in 2015. The high price of land in industrial areas Jakarta caused investors who wanted to expand the industrial sector to discourage investing in Jakarta in 2015. Investors have chosen to move to other areas, so that industrial growth in Jakarta has weakened and even decreased in number, which in turn led to a decrease in labor absorption in 2015. The high investment value, the number of industries, and job opportunities in Jakarta have become a separate magnet that can be attracting residents from the area of origin to migrate to this city. The formulation of problems that can be taken based on the background described above is, how is the influence and how much influence wages, investment, number of industry and job opportunities on in-migration to DKI Jakarta in 2009-2019. By the background and problem formulations that have been described, the purpose of this research is to determine the effect and how much influence wages, investment, number of industries, and employment opportunities for in-migration to DKI Jakarta in 2009-2019. The benefits of this research are: 1.) From the research that the author has done, it is hoped that it can be useful to provide insight and knowledge for readers. 2) It is hoped that this research can also be used as information material and material for consideration for policymakers, especially for leaders, so that the policy direction is made according to what is needed. 3) From this research, the researcher hopes that it can become a benchmark for the Indonesian government in predicting the factors that cause the rise and fall of population migration in Indonesia so that they can evaluate the problems that will arise. 4) As reference material for further researches in the context of developing science. ) From the research that the author has done, it is hoped that it can be useful to provide insight and knowledge for readers. 2) It is hoped that this research can also be used as information material and material for consideration for policymakers, especially for leaders, so that the direction of the policies made is by what is needed. 3) From this research, the researcher hopes that it can become a benchmark for the Indonesian government in predicting the factors that cause the rise and fall of population migration in Indonesia so that they can evaluate the problems that will arise. 4) As reference material for further researches in the context of developing science. ) From the research that the author has done, it is hoped that it can be useful to provide insight and knowledge for readers. 2) It is hoped that this research can also be used as information material and material for consideration for policymakers, especially for leaders, so that the direction of the policies made is by what is needed. 3) From this research, the researcher hopes that it can become a benchmark for the Indonesian government in predicting the factors that cause the rise and fall of population migration in Indonesia so that they can evaluate the problems that will arise. 4) As reference material for further researches in the context of developing science. 2) It is hoped that this research can also be used as information material and material for consideration for policymakers, especially for leaders, so that the policy direction is made according to what is needed. 3) From this research, the researcher hopes that it can become a benchmark for the Indonesian government in predicting the factors that cause the rise and fall of population migration in Indonesia so that they can evaluate the problems that will arise. 4) As reference material for further researches in the context of developing science. 2) It is hoped that this research can also be used as information material and material for consideration for policymakers, especially for leaders, so that the policy direction is made according to what is needed. 3) From this research, the researcher hopes that it can become a benchmark for the Indonesian government in predicting the factors that cause the rise and fall of population migration in Indonesia so that they can evaluate the problems that will arise. 4) As reference material for further researches in the context of developing science. 3) From this research, the researcher hopes that it can become a benchmark for the Indonesian government in predicting the factors that cause the rise and fall of population migration in Indonesia so that they can evaluate the problems that will arise. 4) As reference material for further researches in the context of developing science. 3) From this research, the 
researcher hopes that it can become a benchmark for the Indonesian government in predicting the factors that cause the rise and fall of population migration in Indonesia so that they can evaluate the problems that will arise. 4) As reference material for further researches in the context of developing science.

\section{LITERATURE REVIEW}

Migration according to Caroline (2019) is a population movement that includes permanent or semi-permanent changes of residence specifically. Meanwhile, population movements that are only temporary, such as on a tour, vacation, or business trip, are called commuting and circulation. According to Everet S. Lee (Mantra, 2000), Migration can be defined as a change in a person's residence either permanently or semi-permanently, and there is no distance limit for the change in residence. According to Lee, four factors cause people to migrate, namely: factors of origin, factors found in destination areas, intermediate obstacles, individual factors.Meanwhile, according to the Central Statistics Agency (2015) migration is one of the main components of growth. population, in addition to the components of the birth and death of the population. Population mobility or migration is defined as the movement (movement) of the population across one area to another within a certain period. The economic theory of rural-urban migration is also proposed by Todaro (2004), where it is assumed that rural-urban migration is a phenomenon in the economy. Therefore, the decision to migrate is also a decision that has been formulated rationally. In essence, Todaro (2004) bases the idea that migration flows take place in response to differences in income between cities and villages. They will only decide to migrate if the net income in the city exceeds the net income available in the village. Anwar (2000), Wages are payments in the form of money for work services or money which is usually paid to employees on an hourly, daily, and half-day basis. Meanwhile, Malayu (2002) states that wages are remuneration paid to daily workers with guidelines or agreements that have been agreed upon to pay. According to Devanto and Putu (2011), the minimum wage is a minimum (lowest) monthly income as a reward from employers to employees for a job or service that has been or will be performed. The definition of the minimum wage in Indonesia is based on Ministerial Decree No.1 of 1999 Article 1 paragraph 1, concerning minimum wages. "Minimum wage is the lowest monthly wage consisting of basic wages including fixed allowances". The meaning of the word permanent allowance is an amount of compensation received by employees regularly and regularly paid, which is not associated with attendance or certain achievement. The minimum wage aims to create a decent income for workers. Not much different, according to Adisu (2008), the minimum wage is the lowest monthly wage applicable in each Province (UMP) and Regency / City (UMK) which consists of a basic wage and a fixed allowance. In the framework of the Government's efforts to provide wage protections, a minimum wage is determined which changes every year, whose value depends on the situation and conditions of the national economy. According to Sukirno (2003), an investment can be defined as an expenditure or investment or a company to buy capital goods and production equipment to increase the ability to produce goods and services available in the economy. So from a macro perspective, investment is the action of the corporate sector in buying capital goods and not from the perspective of individuals buying capital goods. This increase in the number of capital goods allows the economy to produce more goods and services in the future. This investment can be divided into state-owned investment (BUMN), private investment, and general government investment. From several theories that have been mentioned, it can be concluded that the definition of investment is the purchase of production equipment and capital goods to increase the ability to produce goods and services needed in the economy (Sutawijaya, 2014). According to (Jhingan, 2014), the formation of capital for the community does not use all of its current productive activities for consumer needs and desires, but only uses a portion for the manufacture of capital goods, such as tools, machine tools. Transport facilities: factories, and all forms of tangible capital that can quickly increase the benefits of productive efforts. Statistics Indonesia (2015), The number of industrial units is some business units carrying out economic activities aimed at producing goods or services located in a certain building or location and having separate administrative records regarding production and cost structure and one or more persons who are responsible for their business. Angraeny (2016), an industrial company is a business unit that carries out economic activities, aims to produce goods or services, is located in a certain building or location, and has separate administrative records regarding production and cost structure and there are one or more people who are responsible for the business. . Various kinds of industries are spread across Indonesia to produce goods or services that will meet the demands of society in various regions. It can be said to be an industry if it meets the criteria, namely annual sales of more than IDR 2,500,000,000.00 up to a maximum of IDR 50,000,000,000.00. (Ministry of Industry and Trade, 1998). According to Jhingan (2014), job opportunities include all jobs filled by all vacant workers. Much of the labor literature continues to use the term employment without translating it as "employment opportunity" which means the number of people employed, regardless of how much work each person has or the amount of time they earn. Ordinary people in the employment statistics in Indonesia define the term "employment opportunities" as often referring to available vacancies or what is called "employment opportunities". Even though in the status of employment in Indonesia, employment opportunity is a translation for employment (Chotib, 2007). Job opportunity according to Sukirno (2001) is a condition in which all workers who wish to work at a certain wage level will easily find work. Job opportunities contain the meaning of employment opportunities and opportunities to work that exist from economic activity (production). Based on the understanding that has been put forward by some of these experts, it can be said that job opportunity is the amount of willingness of the production business to employ the labor needed in the production process, which can mean employment or opportunities available for work that exists from a time of economic activity. is a situation in which all workers who want to work at a certain wage level will easily get a job. Job opportunities contain the meaning of employment opportunities and opportunities to work that exist from economic activity (production). Based on the understanding that has been put 
forward by some of these experts, it can be said that job opportunity is the amount of willingness of the production business to employ the labor needed in the production process, which can mean employment or opportunities available for work that exist from one time in economic activity. is a situation in which all workers who want to work at a certain wage level will easily get a job. Job opportunities contain the meaning of employment opportunities and opportunities to work that exist from economic activity (production). Based on the understanding that has been put forward by some of these experts, it can be said that job opportunity is the amount of willingness of the production business to employ the labor needed in the production process, which can mean employment or opportunities available for work that exist from one time in economic activity.

Todaro and Smith (2014), stated that migration is caused by the power that binds people to their place of origin and forces that encourage people to leave their area of origin. One of the driving forces is the difference in wage levels. The higher the wage difference between rural and urban areas becomes a motivating factor for rural people to migrate to cities, in search of higher income. Angraeny (2016) The relationship between wages is very influential on the level of migration. When wages in the city increase, the income of people in the city will also increase which results in increased consumption of goods and services so that the production of goods and services increases which in turn has an impact on economic growth. This economic growth causes the demand for labor to increase, this is a pull factor for people in rural areas to migrate to cities. Mankiw (2003) states that an increase in investment will hurt economic growth and a positive effect on migration. High economic growth will encourage demand for labor so that the demand for labor will increase. The increase in existing employment opportunities encourages increased migration. This research is related to Astuti (2015), the results of his research show that the investment variable has a positive effect on the number of the migrant population in the 20002010 period in South Sulawesi, but in three provinces (North Sulawesi, Central Sulawesi, and Southeast Sulawesi) in the 2000-2005 period, it has an effect negative. The more investment in an area allows for more job opportunities, because with a large amount of investment, more projects will be created that are financed by investment, so this will be an opportunity for residents of an area to migrate. Angraeny (2016) the amount of investment value will determine the amount of demand for labor, the greater the investment, the greater the additional use of labor. For the development of the industrial sector, it is necessary to have adequate investment so that in developing the industrial sector it can proceed as desired. Capital accumulation efforts can be carried out through investment activities that will drive the economy through the aggregate demand mechanism, which will increase production efforts and in the end will be able to increase the demand for labor and become a pull factor for workers to migrate. so that this will be an opportunity for residents of an area to migrate. Angraeny (2016) the amount of investment value will determine the amount of labor demand, the greater the investment, the greater the additional use of labor. For the development of the industrial sector, it is necessary to have adequate investment so that in developing the industrial sector it can proceed as desired. Capital accumulation efforts can be carried out through investment activities that will drive the economy through the aggregate demand mechanism, which will increase production efforts and in the end will be able to increase the demand for labor and become a pull factor for workers to migrate. so that this will be an opportunity for residents of an area to migrate. Angraeny (2016) the amount of investment value will determine the amount of labor demand, the greater the investment, the greater the additional use of labor. For the development of the industrial sector, it is necessary to have adequate investment so that in developing the industrial sector it can proceed as desired. Capital accumulation efforts can be carried out through investment activities that will drive the economy through the mechanism of aggregate demand, which will increase production efforts and ultimately be able to increase demand for labor and become a pull factor for labor to migrate. the greater the investment, the greater the additional use of labor. For the development of the industrial sector, it is necessary to have adequate investment so that in developing the industrial sector it can proceed as desired. Capital accumulation efforts can be carried out through investment activities that will drive the economy through the aggregate demand mechanism, which will increase production efforts and in the end will be able to increase the demand for labor and become a pull factor for workers to migrate. the greater the investment, the greater the additional use of labor. For the development of the industrial sector, it is necessary to have adequate investment so that in developing the industrial sector it can proceed as desired. Capital accumulation efforts can be carried out through investment activities that will drive the economy through the aggregate demand mechanism, which will increase production efforts and in the end will be able to increase the demand for labor and become a pull factor for workers to migrate.Rizqika (2012) states that the relationship between the number of industrial units and migration has a positive effect. With the expansion of industrial activities in increasing demand for labor, it is influenced by several factors, such as the value of an investment, wages, and the number of business units. One way to expand industrial activities is by developing industrial units, especially industries that are labor-intensive. The growth of the business unit of a sector in an area will increase the number of jobs, the demand for labor will also increase. If the business unit of an industry is added, the demand for labor will also increase. The increase in demand for labor encourages increased migration. Chotib (2007) states that the number of job opportunities that exist has a positive effect on migration. The growth of job opportunities is closely related to the growth of employment, along with the increase in employment, there will be more job opportunities in big cities, this will encourage rural residents to migrate to cities to find alternatives and work with higher wages. Todaro (2004) in his research shows that job opportunities have a positive influence on migration, according to Todaro, migration is caused by the power that binds people to live in their place of origin and forces that encourage people to leave their area of origin. One of the driving forces is the narrowing of job opportunities at the place of origin. 


\section{METHODOLOGY}

To solve a problem, a certain method or method is used by the subject matter to be discussed. The method used in this research is descriptive quantitative and verification methods. According to Nazir (2003), the descriptive method is a method of examining the status of human groups, an object, a condition, a system of thought, or a class of events in the present. The descriptive method aims to make a systematic, actual, and accurate description of the facts, characteristics, and influences between the phenomena being studied. Quantitative research according to Sugiyono (2017) is data in the form of numbers or quantitative data that is extrapolated or research that emphasizes the analysis of numerical data (numbers). Verification analysis is intended to determine the relationship between the independent variable and the dependent variable. According to Sugiyono (2017), the verification method is a study that aims to determine the relationship between two or more variables. In analyzing the data, the method used is multiple linear regression analysis using the Ordinary Least Square (OLS) least-squares method. OLS is a method used to estimate classical regression coefficients by minimizing the number of squares of errors (Khotijah, 2008). The OLS method has several advantages, namely that it is technically very easy to draw interpretations and calculations and assessments of BLUE (Best Linear Ungawai Estimator). The BLUE estimators are: According to Sugiyono (2017) the verification method is a study that aims to determine the relationship between two or more variables. In analyzing the data the method used is multiple linear regression analysis using the Ordinary Least Square (OLS) least-squares method. OLS is a method used to estimate classical regression coefficients by minimizing the number of squares of errors (Khotijah, 2008). The OLS method has several advantages, namely that it is technically very easy to draw interpretations and calculations and assessments of the BLUE (Best Linear Ungawai Estimator). The BLUE estimators are: According to Sugiyono (2017) the verification method is a study that aims to determine the relationship between two or more variables. In analyzing the data the method used is multiple linear regression analysis using the Ordinary Least Square (OLS) least-squares method. OLS is a method used to estimate classical regression coefficients by minimizing the number of squares of errors (Khotijah, 2008). The OLS method has several advantages, namely that it is technically very easy to draw interpretations and calculations and assessments of the BLUE (Best Linear Ungawai Estimator). The BLUE estimators are: OLS is a method used to estimate classical regression coefficients by minimizing the number of squares of errors (Khotijah, 2008). The OLS method has several advantages, namely that it is technically very easy to draw interpretations and calculations and assessments of the BLUE (Best Linear Ungawai Estimator). The BLUE estimators are: OLS is a method used to estimate classical regression coefficients by minimizing the number of squares of errors (Khotijah, 2008). The OLS method has several advantages, namely that it is technically very easy to draw interpretations and calculations and assessments of BLUE (Best Linear Ungawai Estimator). The BLUE estimators are:

[1] Best, the results of the regression model are the best and produce small errors.

[2] Linear, the model used in regression is by the OLS model rules, namely linear and the highest rank of the variables is one.

[3] Unavailable, the expected value of the estimate equal to or close to the actual parameter value.

[4] Estimator, the regression model that is formed has minimal variance from other estimators.

\section{Analysis Model}

The economic model used in this study is as follows:

$\mathrm{MM}=\beta 0+\beta 1 \mathrm{UMPt}+\beta 2 \mathrm{INVt}+\beta 3 \mathrm{UINt}+\beta 4 \mathrm{KKJt}+\varepsilon \mathrm{t}$

Information :

$\mathrm{MM}=$ Incoming migration

UMPt $=$ Provincial Minimum Wage in a certain period

$\mathrm{INVt}=$ Investments in a certain period

UINt $=$ Number of Industrial Units in a certain period

$\mathrm{KKJt}=$ Job opportunities for a certain period

$\beta 0=$ Intercept or constant

$\beta 1, \beta 2, \beta 3$, and $\beta 4=$ Estimator or regression coefficient for each variable

$\mathrm{t}=$ time

$\varepsilon \quad=$ Nuisance, residual, or error term factors

\section{RESULT AND DISCUSSION}

\subsection{Static Test and Econometric Test}

In this study, to see the effect of wage, investment, industrial units, and employment variables on in-migration to DKI Jakarta, it is necessary to carry out statistical tests and econometric tests. Statistical and econometric tests can be determined by estimating the variables under study, estimating the migration function is carried out by multiple linear 
regression analysis and the method used is the least-squares method or the method of Ordinary Least Square (OLS) while the data processing operations are carried out with the Eviews7 software.

Table 2. Estimation Results

\begin{tabular}{crrrr}
\hline Variable & Coefficient & Std. Error & t-Statistic & Prob. \\
\hline C & 29210.95 & 44040.33 & 0.663277 & 0.5284 \\
UMP & 0.046079 & 0.014034 & 3,283359 & 0.0134 \\
INV & $-1.99 \mathrm{E}-09$ & $5.88 \mathrm{E}-10$ & -3.377753 & 0.0118 \\
UIN & -4.639967 & 27.03145 & -0.171651 & 0.8686 \\
KKJ & -0.062883 & 0.094429 & -0.665933 & 0.5268 \\
\hline
\end{tabular}

Source: Eviews7 data processing results

\subsubsection{Statistical Test}

To get a standard value of proportional regression coefficients, each independent variable will be tested using statistical tests. Based on the estimation results in table 4.1, the F-test and -t-test results are obtained as follows:

[1] T-test

The t-test is used to test the significance of the effect of the variable wages (UMP), investment (INV), industrial units (UIN), and job opportunities (KKJ), partially on the variable in-migration (MM) to DKI Jakarta. The econometric software used in the analysis is Eviews7.

Table 3. T-Test Results

\begin{tabular}{crrrl}
\hline Independent variable & \multicolumn{1}{c}{ t-count } & t-table & Prob. & \multicolumn{1}{c}{ Information } \\
\hline UMP & 3,28335 & 2.3060 & 0.0134 & Significant at $\alpha=0.05$ \\
INV & -3.37775 & 2.3060 & 0.0118 & Significant at $\alpha=0.05$ \\
UIN & -0.17165 & 2.3060 & 0.8686 & Not significant at $\alpha=0.05$ \\
KKJ & -0.66593 & 2.3060 & 0.5268 & Not significant at $\alpha=0.05$ \\
\hline
\end{tabular}

Source: Eviews7 data processing results

[2] F test

This test is conducted to determine the significance level of the influence of the independent variables (wages, investment, industrial units, and job opportunities) on the dependent variable (in-migration). The tool used in this analysis is eviews7. Based on the analysis, F count (5.141767) is greater than F table (4.07) which means that Ho is rejected, when Ho is rejected, the wage variable (UMP), investment (INV), industrial unit (UIN), and job opportunities (KKJ) together affect the variable in-migration (MM) to DKI Jakarta.

\subsubsection{Econometric Test}

The model produced before being used for hypothesis testing is tested to get the "best fit model". The test is done by using the econometric test.

\section{[1] Multicollinearity Test}

A multicollinearity test is a test used to see the correlation between the dependent variable. To determine the existence of multicollinearity, it can be obtained by comparing the $\mathrm{R}^{2}$ value of the model with the $\mathrm{R}^{2}$ auxiliary of the independent variables. If $\mathrm{R}^{2}$ model $>\mathrm{R}^{2}$ Auxiliary it is said that the equation does not contain multicollinearity. The econometric software used in the analysis is Eviews7. After doing the test, the results showed that there was no multicollinear problem because the coefficient of determination value between the independent variables was smaller than the coefficient of determination of the empirical model function (R2> R21, R22, R23, R24).

[2] Heteroscedastic Test

This test is intended to determine the variation of the disturbance factors from each variable to the dependent variable. To detect heteroscedasticity, tests can be carried out, among others, by using the Glejser test. The econometric software used in the analysis is Eviews7. Based on the results of the heteroscedastic test using the Glejtser method, the Obs* R-squared value of 4.536326 is smaller than the chi-squared table value of 21.026, which means that Ho is accepted, then there is no heteroscedastic problem in the model.

[3] Normality test

The normality test is a test that is carried out to assess the distribution of residuals in the regression results, whether the residuals are normally distributed or not. The econometric software used in the analysis is Eviews7. Based on the results of the normality test, it was found that the Jarque Bera probability was greater than the real level used (0.261579> 0.05). Based on this, there is sufficient evidence to accept H0, which means that the residuals in the model are normally distributed or it can be said that the model used is fit for use.

[4] Autocorrelation Test 
In regression analysis, the autocorrelation test is a test used to determine whether there is a correlation between residuals in the model. The econometric software used in the analysis is Eviews7. Based on the results of the estimation, the probability value of 0.2524 is greater than $\alpha 0.05$, which means that Ho is accepted. So with a $95 \%$ confidence level, it can be said that there is no autocorrelation problem in this model.

[5] Linearity Test

The linearity test is a test that aims to determine whether the model used has linear specifications or not. For multiple linear regression, testing for linearity can use the Ramsey Reset Test. The econometric software used in the analysis is Eviews7. The results of the linearity test show that the probability of F count is greater than the real level used $(0.8877>0.05)$. Based on this, there is sufficient evidence to accept $\mathrm{H} 0$, which means that the regression model has met the linearity assumption.

\subsection{Economic Analysis and Discussion}

After conducting statistical tests and econometric tests using eviews7 software, the results show that from four independent variables (wages, investment, industrial units, and job opportunities) it turns out that two variables have a partial effect on the dependent variable (inbound migration) to DKI Jakarta. The two influencing variables are the wage variable (UMP) and the variable (INV), while the other two variables of an industrial unit (UIN) and job opportunity (KKJ) are stated partially to not affect in-migration (MM) to DKI Jakarta in 2008- 2019. This matter is influenced by several things, including the high cost of living in the city of Jakarta, the number of new industrial units emerging in the Jakarta buffer city, and the many job opportunities that can be obtained in the Jakarta buffer city.

\subsubsection{The Influence of Provincial Minimum Wages, Investment, Industrial Units, and Employment Opportunities for} Incoming Migration to DKI Jakarta

To see how the variables of wages, investment, number of industries, and job opportunities partially influence inmigration to DKI Jakarta in 2008-2019, we can get it by looking at the t-test values listed above. The results of the t-test show that:

[1] The Effect of Provincial Minimum Wages on Incoming Migration to DKI Jakarta

Based on the results of the estimation model, it shows that partially the provincial minimum wage (UMP) has a positive and significant effect on in-migration (MM) to DKI Jakarta in 2008-2019. The value of the elasticity coefficient of the UMP variable is 0.0460 with a positive sign, meaning that if the UMP increases by 1 million rupiahs, the in-migration will increase by 46,000 people or vice versa, assuming other variables are considered constant (ceteris paribus). The results of this study are appropriate. with the research hypothesis which states that there is an effect of the provincial minimum wage on incoming migration.

[2] The Influence of Investment on Incoming Migration to DKI Jakarta

Based on the estimation model results, it shows that partial investment (INV) has a negative and significant effect on in-migration (MM) to DKI Jakarta. The value of the investment variable elasticity coefficient of -1.9870 with a negative sign means that if, for example, investment realization increases by 1 million rupiahs, the in-migration will decrease by 1.98 people or vice versa, assuming other variables are considered constant (ceteris paribus). The investment variable has a negative effect because the sector that absorbs the largest investment in Jakarta is the tertiary sector, namely the trade and repair business field, the hotel and restaurant business field, the transportation and telecommunications business field, as well as the financial and services business fields. Can be seen in table 4 . 7 where the tertiary sector always has the largest contribution to the GRDP of DKI Jakarta in 2008-2019. Investments in the tertiary sector have been used for several years to increase capital, not to increase labor. Investments are used to buy modern computer-operated equipment so that human workers are no longer needed in the tertiary sector because they are replaced by machines. This matter is the cause of low labor absorption in the tertiary sector. The low absorption of labor in Jakarta has resulted in people who want to migrate to Jakarta to prefer to migrate to other areas. Investments are used to buy modern computer-operated equipment so that human workers are no longer needed in the tertiary sector because they are replaced by machines. This matter is the cause of low labor absorption in the tertiary sector. The low labor absorption in Jakarta has resulted in people who want to migrate to Jakarta to prefer to migrate to other areas. Investments are used to buy modern computer-operated equipment so that human workers are no longer needed in the tertiary sector because they are replaced by machines. This matter is the cause of low labor absorption in the tertiary sector. The low absorption of labor in Jakarta has resulted in people who want to migrate to Jakarta to prefer to migrate to other areas.

[3] The Effect of Industrial Units on Incoming Migration to DKI Jakarta

Based on the results of the estimation model, it shows that partially the Industrial Unit (UIN) at the 95 percent confidence level has no significant effect on Incoming Migration (MM) to DKI Jakarta in 2008-2019. The results of this study are not by the research hypothesis which states the influence of industrial units on incoming migration. The industrial unit has no effect on in-migration to Jakarta in 2008-2019 because the industrial sector in Jakarta in the 2008-2019 period always went up and down while the industry in the Jakarta buffer zone continued to increase. With the growth of new industrial estates around Jakarta, interest in migration is no longer concentrated in Jakarta but is divided into places that have more industries.

[4] The Effect of Job Opportunities on Incoming Migration to DKI Jakarta 
Based on the estimation model results, it shows that partially the Job Opportunity (KKJ) at the 95 percent confidence level does not have a significant effect on Incoming Migration (MM) to DKI Jakarta in 2008-2019. The results of this study are not by the research hypothesis which states that work opportunities affect in-migration. This happens because existing job opportunities require more specific skills, so even though there are job opportunities, they are unable to absorb a large number of job seekers. The industry that is developing in Jakarta uses more capital than labor.

\subsubsection{Magnitude of Influence}

Based on the estimation results in Table 4.1, we can know the percentage of variations in the Provincial Minimum Wage, Investment, Industrial Unit, and Job Opportunity variables which can explain variations in the level of Incoming Migration to DKI Jakarta in 2008-2019. We can get the percentage of variation by looking at the coefficient of determination (R-squared) obtained in Table 4.1. Based on the estimation results in Table 4.1 above, it is known that the coefficient of determination ( $\mathrm{R}$ square) is equal to 0.746074 or equal to $74.6074 \%$. The interpretation of this $\mathrm{R}$-squared value is that the variable wages (UMP), investment (INV), number of industrial units (UIN), and number of job opportunities (KKJ) are simultaneously (together) able to explain the variable variation of incoming migration (MM). amounting to $74.6074 \%$. While the remaining 25 ,

\section{CONCLUSIONS}

The independent variables of the provincial minimum wage, investment, industrial units, and job opportunities together have a significant effect on the dependent variable, namely in-migration to DI Jakarta in 2008-2019. Partially the provincial minimum wage and investment have a significant effect on the dependent variable, namely in-migration. Meanwhile, industrial units and job opportunities do not affect in-migration to DKI Jakarta 2008-2019. The R-Square value is 0.746074 . This indicates that the variable provincial minimum wage, investment, industrial units, and job opportunities simultaneously (together) affect the incoming migration variable (MM) by $74.6074 \%$. While the remaining $25.3926 \%$ is explained by other factors outside the regression equation.

\section{ACKNOWLEDGMENT}

The author would like to thank both parents, family, and friends who have given their encouragement and support. The author also wishes to express his deepest gratitude to all Development Economics lecturers who have provided knowledge and do not forget to thank the alma mater of the Islamic University of Bandung, which is the place for writers to seek knowledge. The author also thanks to all respondents from this research for all their assistance, time, and willingness to assist the author so that the author can complete this research.

\section{REFERENCES}

Adisu, Marhaeni. 2008. Buku Ajar Ekonomi Sumber Daya Manusia. Fakultas Ekonomi Universitas Udayana.

Angraeny, Ayu. 2016. Pengaruh Upah, Investasi Dan Jumlah Unit Industri Terhadap Tingkat Migrasi Di Kota Makassar Tahun 2004-2013: FE UIN Alaudin Makasar. Makasar.

Anwar, Sumarsono. 2000. Ekonomi Manajemen Sumber Daya Manusia, Penerbit Graha Ilmu, Yogyakarta

Badan Pusat Statistik. 2007. Jakarta Dalam Angka 2006. Jakarta, Badan Pusat Statistik.

Badan Pusat Statistik. 2008. Jakarta Dalam Angka 2007. Jakarta, Badan Pusat Statistik.

Badan Pusat Statistik. 2009. Jakarta Dalam Angka 2008. Jakarta, Badan Pusat Statistik.

Badan Pusat Statistik. 2010. Jakarta Dalam Angka 2009. Jakarta, Badan Pusat Statistik.

Badan Pusat Statistik. 2010. Persentase Penduduk Menurut Status Migran, Hasil Sementara Sensus Penduduk, Makassar.

Badan Pusat Statistik. 2011. Jakarta Dalam Angka 2010. Jakarta, Badan Pusat Statistik.

Badan Pusat Statistik. 2012. Jakarta Dalam Angka 2011. Jakarta, Badan Pusat Statistik.

Badan Pusat Statistik. 2013. Jakarta Dalam Angka 2012. Jakarta, Badan Pusat Statistik.

Badan Pusat Statistik. 2014. Jakarta Dalam Angka 2013. Jakarta, Badan Pusat Statistik.

Badan Pusat Statistik. 2015. Jakarta Dalam Angka 2014. Jakarta, Badan Pusat Statistik.

Badan Pusat Statistik. 2016. Jakarta Dalam Angka 2015. Jakarta, Badan Pusat Statistik.

Badan Pusat Statistik. 2017. Jakarta Dalam Angka 2016. Jakarta, Badan Pusat Statistik.

Badan Pusat Statistik. 2018. Jakarta Dalam Angka 2017. Jakarta, Badan Pusat Statistik.

Badan Pusat Statistik. 2019. Jakarta Dalam Angka 2018. Jakarta, Badan Pusat Statistik.

Badan Pusat Statistik. 2020. Jakarta Dalam Angka 2019. Jakarta, Badan Pusat Statistik.

Caroline.2019. Kajian Dan Kebijakan Migrasi Tenaga Kerja Provinsi Jawa Tengah.Media Sahabat Cendekia. Surabaya.

Chotib. 2007. Pengaruh Investasi dan tingkat upah terhadap kesempatan kerja di Jawa timur. Jurnal. Surabaya: FE UNS.

Dewi . 2013. Faktor-Faktor Yang Mempengaruhi Minat Migran Melakukan Mobilitas Non Permanen Ke Kota Denpasar. UNJ. Jakarta

Devanto et.al. 2011. Pengaruh Migrasi dan Tenaga Kerja Terhadap PDRB ， Jember. Jurnal FE UNEJ Vol.2 (1).

Jhingan, M.L. 2014. Ekonomi Pembangunan dan Perencanaan. Jakarta: Rajawali Pers.

Kemenperindag. No.497 Tentang Petunjuk Pelaksanaan Program Pemberdayaan Industri Kecil Dan Menengah Serta Pedagang Kecil dan Menengah. 1998. Jurnal Ekonomi. FE Universitas Riau, Vol 21 No2.

Khotijah, Siti. 2008. Analisis Faktor Pendorong Migrasi Warga Klaten Ke Jakarta. UNDIP. Semarang

Lee, E. 2000. Suatu Teori Migrasi. Pusat Penelitian Kependudukan Universitas Gajah Mada, Yogyakarta.

Mantra, I. B. 2000. Population Movement in Wet Rice Communities. Gajah Mada University Perss, Yogyakarta.

Rizal. 2004. Analisis Faktor-Faktor Yang Mendorong Seseorang Unuk Melakukan Migrasi Ulang-Alik Di Kota Medan. Skripsi. Malang.

Sukirno, Sadono. 2001. Pengantar Teori Makro Ekonomi. Jakarta: Rajawali Pers. 
Trisetiyo, et al. The Effect of Wages, Investment, Number of Industrial Units, and Number of Job Opportunities on the Level of

Sukirno, Sadono. 2003. Pengantar Teori Makro Ekonomi. Jakarta: Rajawali Pers.

Sutawijaya, Adrian. 2014. Pengaruh Ekspor dan Investasi Terhadap Pertumbuhan Ekonomi Indonesia Tahun 1980-2006. Jurnal Organisasi dan Manajemen vol.6 (1)

Tjahyati, Budi. 2016. Mobilitas Penduduk dan Pengaruhnya terhadap Pembangunan Daerah. Kantor Menteri Negara Kependudukan/BKKBN. Jakarta

Todaro and Smith, Stephen C. 2014. Economic Development 11th Edition Ch7.

Todaro dan Smith. 2004. Pembangunan Ekonomi di Dunia Ketiga. Edisi Kedelapan. Erlangga, Jakarta.

Tjiptoherjanto. 1999. Studi Tentang Pola Migrasi Migran Sirkuler Asal Wonogiri ke Jakarta. UGM. Yogyakarta. 